\title{
The Process of Environmental Institutionalization in
}

\section{Mozambique}

\author{
Giverage Alves do Amaral \\ State University of Campinas (UNICAMP/NEPAM), Rio de Janeiro, Brazil
}

\begin{abstract}
The late 1980s began a transition from a centrally planned economic system to a market economy in Mozambique. This transition was marked by a gradual decentralization of public administration and the cross consideration of environmental issues. In our times, research and environmental studies are globally centrals to multiples fields of knowledge, based on this we try to reflect on the process of institutionalization of environmental issues in Mozambique. Our goal is to analytically explorer the political, social and economic contours that allow characterizing the beginning of this process. This article is the result of exploratory research using the qualitative method of analysis. The results showed that the beginning of the environmental issue institutionalization process in Mozambique was the result of various government initiatives and financial demands inherent in the development process, and filled in rhetorical strategies of different styles and motives, being pierced by political conflicts and financial, both at the state level as the meagerly existing civil society in this period. In this paper, we present and analyzed the socio-historical circumstances that interspersed the process of environmental institutionalization, indicating exogenous and endogenous factors that proved decisive for the current environmental institutional status in Mozambique.
\end{abstract}

Keywords: Mozambique, environment, institutionalization, economics and environmental policy

\section{Introduction}

The environmental perspective the decade of 1980s was a novel issue for many states and governments around the world, especially for those so-called developing countries, as is the case of Mozambique. Officially, the Republic of Mozambique is an African country located on the east coast of Southern Africa. Bordered to the north by Tanzania, northwest Zambia and Malawi, west Swaziland and Zimbabwe, the south and west by South Africa and the east by the Mozambique Channel where is maritime borders.

In the period before independence (1975), it was possible to note that the environmental issue in Mozambique never received the same importance in all the development efforts as these days, limited to only a few conservation measures for forests, wildlife and sporadic actions for coastal protection. Only from the late 1980's that the environmental issue began to receive special attention at the government level [National Environmental Management Program (PNGA), 1995].

Since the late 1980s, the Mozambican government setup in 1975, adopted the environmental perspective

\footnotetext{
Giverage Alves do Amaral, Ph.D., Department of Sociology, State University of Campinas (UNICAMP/NEPAM).
} 
globally dominant, according to which anthropogenic activities constituted a growing global concern for causing damage to the environment and climate system, endangering life on earth. Thus, as regards the environmental policies, domestic legislation, sectoral strategies and programs or projects developed in the context of an environmental institutionalization process, government emphasis was placed on the need to achieve sustainable development, which would be the solution to victory in the fight against absolute poverty. This approach proved to be a strong indicator of which perspective Mozambique had adopted face global environmental problems, and internally why ratified several conventions on environmental protection at a glance (Amaral, 2014a).

Indeed, the Mozambican government has adhered to various global initiatives in order to allow the planet remains habitable for the present and future generations, especially: the African Convention on the Conservation of Nature and Natural Resources (Algiers, 1968, Resolution No. 18/81, of December 30, ratified in Maputo on 11 July 2003). The Kyoto Protocol (1992, signed and ratified by Mozambique on 18 January 2005, this Protocol expired in 2012); The UN Framework Convention on Climate Change (Rio, 1992 was ratified by Mozambique on 24 August 1994); The Convention of Stockholm (1972, ratified on 23 May 2001). Resolution No. 11/2001 of 20 December 2001 (which ratified the Cartagena Protocol on Biosafety); The Resolution ratifying the Convention on the Conservation of Wild Migratory Species (signed in Bonn, Germany, on 23 July 1979 and the respective 1985 Amendments, 1988, 1991, 1994, 1997, 1999, 2002 and 2005). The UN Declaration on Human Settlements-Habitat Agenda (2001), the Millennium Declaration (September 2000); the Action Plan for Sustainable Development-Agenda 21 (Eco-92 or Rio-92); Resolution No. 19/96 of 26 November (ratifying the Bamako Convention on the Prohibition of Import of Hazardous Waste and the Movement Control Transfrontier this waste in Africa); Resolution No. 8/93 of 8 December (which ratified the Vienna Convention of 22 March 1985 on the Ozone Layer Protection as well as the respective amendments London 1990 and Copenhagen 1992). The conventions discussed at international level (in the city of Rio de Janeiro, Brazil, 1992), a conference convened by the United Nations Resolution 44/228 on Sustainable Development, made compulsory the compatibility of their ideas and the process of macroeconomic development planning in each country, although as a crosscutting issue ${ }^{1}$.

In this research, we reflect on what socio-historical circumstances that permeated the beginning of this process of environmental institutionalization in Mozambique? What exogenous and endogenous factors were instrumental in this process? What influences exerted to the current institutional status of environmental issues in the country?

\section{Government and Environment in Mozambique}

The social context Mozambican 1980s and 1990s, was marked by political and economic instability. Mozambique made profound changes, since the transition, from a situation of war, destruction and population displacement to a peaceful situation, national reconstruction, government transition and one-party parliament for the establishment of democratic institutions, a centralized economy to a market economy, a centralized state to a decentralized and participatory governance system. Some of these aspects remain a national challenge today; however, Mozambique is now a presidential republic, whose government is appointed by the President of the

\footnotetext{
1 For further information, please refer to Mozambique, Official Government Portal. Retrieved March 15, 2013, from http://www.portaldogoverno.gov.mz/, http://www.micoa.gov.mz/, http://www.legisambiente.gov.mz/
} 
Republic elected by universal suffrage. It has a Parliament, having held five elections since 1994, they are currently registered 46 political parties, among which three are ecologists (Amaral, 2014a).

Since the beginning of the 1990s, the political practice in Mozambique showed democratic deficits, however, it is important to retain at this point is that institutional reforms were beginning, linked to a need for further structural definitions, implementation of emerging sectoral policies, which resulted in a strict structural adjustment program with great reflection on the political, social, economic and environmental. These changes enabled the rapid insertion of Mozambique in the various political and economic bodies globally. Indeed, this country has to take part as a member of the UN, the African Union (AU), the Community of Portuguese Speaking Countries (CPLP), the Commonwealth, the Southern African Development Community (SADC) since 1996, also the Organization of the Islamic Conference (OIC) (PNGA, 1995; Amaral, 2014a).

Laws and policies relating to the environment, fall into the principles set by the first constitution of the Republic of Mozambique (1990) and 2004 in the current, by Law No. 20/97 of 1 October. But known for Environmental Law and the rules approved by the Council of Ministers and aims to promote the sustainable use of natural resources, fighting for the inclusion of environmental principles and practices in the national reconstruction effort and development of the country, establishing policies and appropriate legislation for this purpose.

The Constitution of the Republic of Mozambique (CRM) affirms, The State shall promote initiatives to guarantee the ecological balance and the conservation and preservation of the environment, with the objective of improving the quality of life of Mozambican citizens. With the purpose to guarantee the right to the environment in the context of sustainable development, the Mozambican State has adopted many policies to integrate environmental objectives into sectoral policies. Such as, preventing pollution and erosion, promote the integration of environmental values policies and education programs, ensure the rational use of natural resources to safeguard its capacity for renewal, and promoting regional planning in order to active an efficient allocation of activities, in a balanced socio-economic development plan.

The Constitution of the Republic of Mozambique, in its Article 90 establishes as a fundamental right of Mozambican citizens to live in a balanced environment and the duty to defend. The state has its increased responsibilities in that he himself be the owner of the natural resources located in the soil and the subsoil, in inland waters, in the territorial waters on the continental shelf and the exclusive economic zone. As discusses in Article 98 of the CRM (2004), and this is the internally aspect that justifies a creation or adoption of concrete measures and coordinates. The region and the world in general, with a view to expanding actions that converge to the rational use of natural resources and the maintenance of environmental balance. It comprised these liabilities in the 1990s internally; policies were created and sectoral strategies with a variety of key aspects that respect the principles for sustainable use of natural resources, environmental conservation, in favor of sustainable development.

In this perspective, Mozambique has a national environment policy approved by Resolution No. 5/95, of 3 August, which is the basis for sustainable development. The enviromental policy aim the progressive elimination poverty and improving quality of life as well as reducing the damage on the environment. The main objective is to ensure an acceptable and realistic compromise between the socio-economic progress and environmental protection, as well, an sustainable development, considering the country specific conditions. 
The sectoral policy Mozambican legal framework presents: (1) The Industrial Policy and Strategy; (2) The National Land Policy and its implementing strategies; (3) Energy policy; and (4) The Policy and Forestry and Wildlife Development Strategy. As noted earlier, the principle of integrated management of natural resources was a novelty that emerged as result of the change of a conservationist view of nature and its resources, particularly flora and wildlife, for the adoption of the sustainability paradigm.

The idea of nature protection expressed by the adoption of measures for the protection of certain animal and plant species, with poor results because they weren't focused on all of the ecosystems that these species were part. It was with the Stockholm conference (1972, 4th principle) that proceeded to link the conservation of flora and fauna and the protection of its ecosystem, abandoning the insulating protection perspective of certain endangered species. Just 20 years later, in 1992, with the United Nations Convention on Climate Change, which Mozambique has ratified, progress has been a key step in the perception of the concept of integrated management and its operation.

It is in this context that begins a set of actions to organize a proposed environmental law to the Mozambican state. Thus, following RIO-92 guidelines and the enthusiasm of the subsequent environmental movement in the second half of the 1990s, the Mozambican legal framework was equipped, becoming composed of various bodies and legal instruments, namely: National Commission of the Environment (CNA, June 1992); Ministry for Environmental Coordination (MICOA, 1994); Law No. 20/97, promulgated on 01 October 1997. That appears with the aim to be in a basic legal framework for the proper management of the environment and its resources to ensure the development sustainable, long-sought national and international level. This law contains a directly related supply with environmental degradation, prohibiting activities that may adversely affect the quality of the environment in Mozambique, and likewise ensures the establishment of environmental quality standards in order to encourage the development of appropriate procedures the different social activities (PNGA, 1995).

To this end, the Act requires that all development projects in the country first must be subjected to an Environmental Impact Assessment (EIA), which consist of the analysis, quantitative and qualitative identification of earnings and damages. This global principle of environmental integration develops and is added Mozambican legislation through environmental law when exposed as a fundamental principle environmental vision as a set of interdependent ecosystems, natural or constructed, which must be managed in order to save functional balance without transcending its natural limits. Thus, it can be concluded that integrated environmental management, would mean the adoption of nature protection measures, with a view to protecting the species that compose it and the ecosystems that allow their survival.

Thus, environmental law (1997) provided a new legal framework to allow the requirement for an environmental license to enterprises whose activities show potential to harm the environment and forces that are involved local people in the process of making environmental decision. Mozambique's environmental policy aims to establish the use and management of environmental components to not only promote the improvement of quality of life, but also aims at the valorization of the traditions and knowledge of local communities for the conservation and preservation of natural resources, and hold them accountable in case of purposeful acts that generate environmental degradation.

For realization of the objectives set forth in the law, as well as for its implementation, were approved different instruments, such as the regulation on environmental quality standards and effluents emission, the 
regulation on management of biomedical waste, the evaluation of environmental impact and regulation, and the Regulation on the environmental audit process. As well as varied sectoral legislation on protection and preservation of the environment, such as "Regulation on Environmental Impact Assessment Process; The Land Law, Law No. 19/97 of 1 October; and The Law of Forestry and Wildlife, Law 10/99 of July 7". However, there are other instruments that make up the framework of the Mozambican environmental policy, such as, petroleum law; law No. 03/2001, of 3 October, the Mining Law, Law No. 14/2002 of 26 June, the Tourism Law, and Law No. 04/2004, of 17 June.

\section{Demographic Aspects and Environment In Mozambique}

Environment and society are interdependent variables in continuous interaction, which implies that any change in one variable, often leads to a change in another (McElroy \& Townsend, 1996, pp. 24-25). In the academic context, for analytical issues we tend to address these aspects in separate.

They think of them as cause and effect processes intrinsic and isolated changes. However, we can think of these interdependent variables functioning as a single unit, according to the interdisciplinary approach of the new ecological paradigm (NPE; Catton \& Catton, 1978a; Catton \& Dunlap, 1980a; Catton, W. R., \& Dunlap, 1994). These authors suggested that by adopting this look at the whole, we would have a model of an ecosystem where all physical, biological and cultural components form a complete ecosystem, a set of relationships between organisms and their environment, just as we consider in this article.

The Mozambican population has a rapid growth over time. Indeed, the 1980 census established the number of Mozambican population 12,102,619 inhabitants, and in mid-1994, the population had increased to 16.6 million, registering a $2.7 \%$ growth in the decade of the 1980's and $2.8 \%$ in the 1990s. The 2007 census followed pointing to continued growth of the Mozambican population, estimated at about 21 million Mozambicans that time, representing an increase of $27.8 \%$ compared to 16,099,246 inhabitants recorded in the previous census (1997). Analyzing Rural/urban dichotomy, we find that the urban population totaled 6,282,632, equivalent to $30 \%$ of the total population of the country. Urban masculinity rate was $48.7 \%$ as result of a total of $9,897,116$ urban men and $10,682,149$ urban women. The remaining $70 \%$ of the population is living outside the city and in the fields.

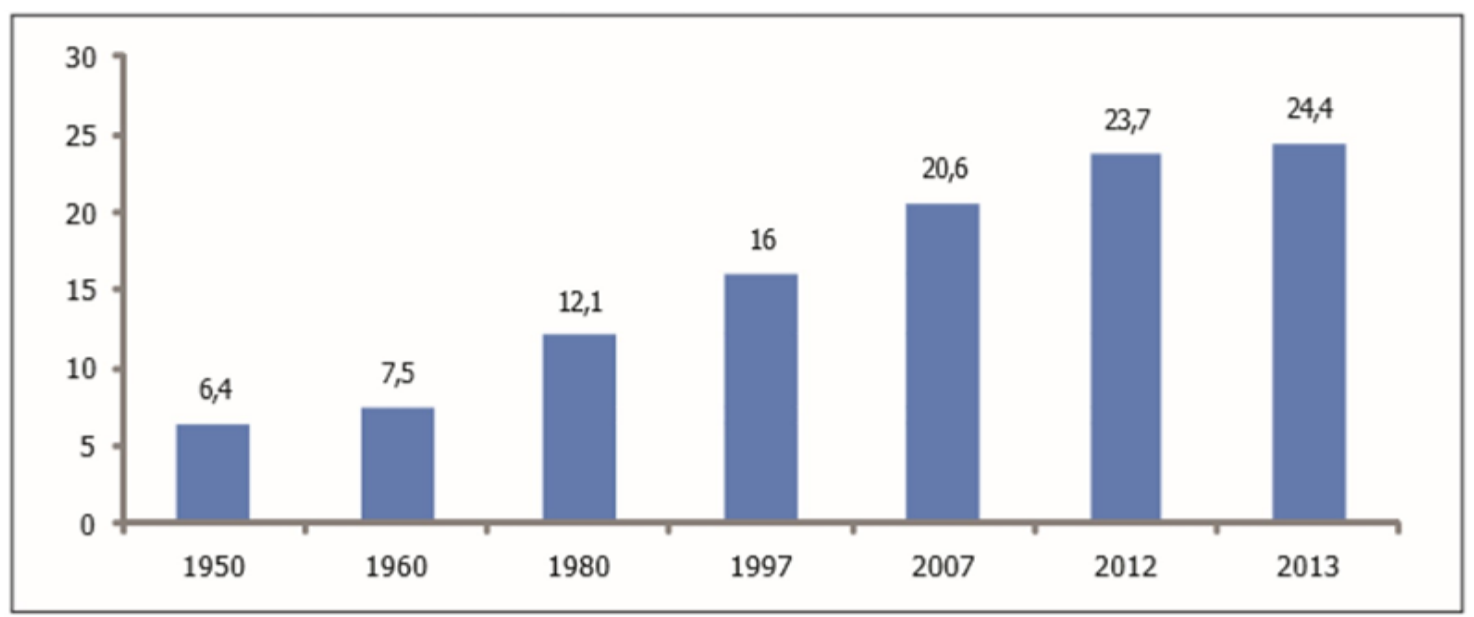

Figure 1. Population evolution, Mozambique 1995-2013.

Source: National Bureau of statistics/ Unit population and planning, 1993 INE. 
This rapid population growth in this period from 1980 to today, fundamentally because the Mozambican population is mostly young, about $44.4 \%$ of the total population is less than 15 years, and the fact that the birth rate has remained stable and reduced mortality rates. Today, eight years later, the numbers are at 25 million, with predictions in 2040 reaching 46,181,058 inhabitants (INE, 2015) ${ }^{2}$.

Graphically this demographic increase is well outlined by the National Statistics Institute in Figure 1 (INE, 2015).

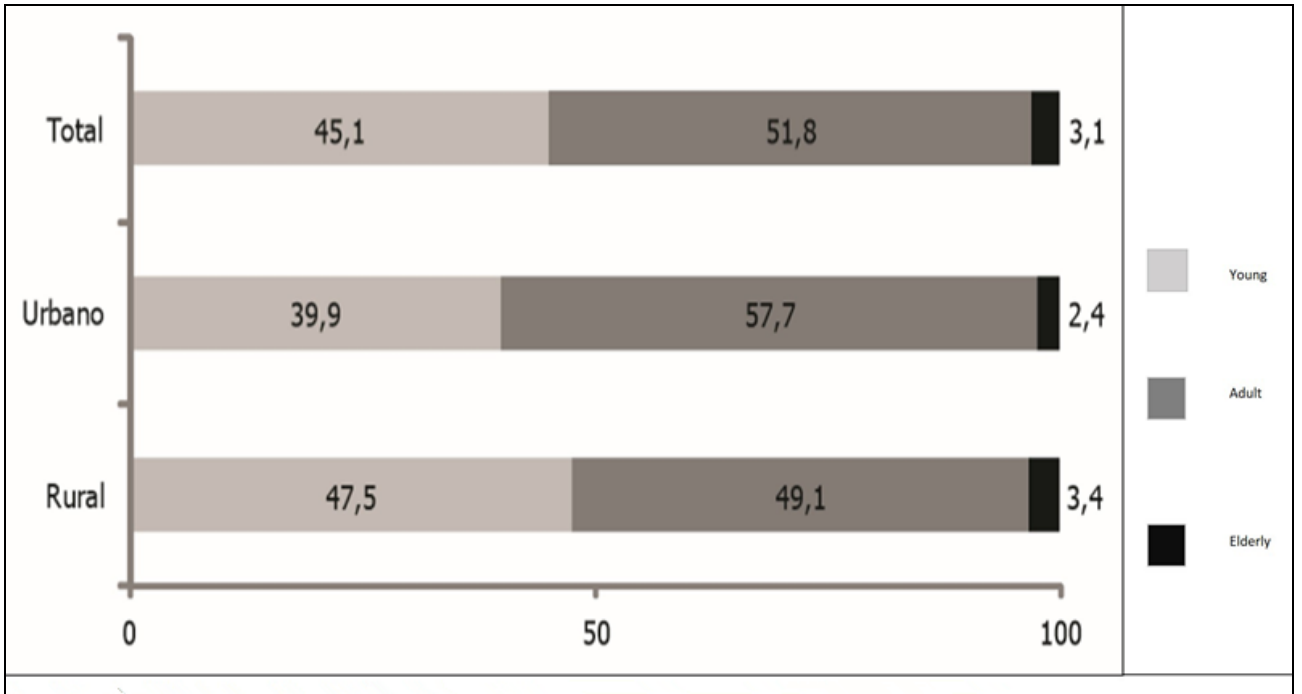

Figure 2. Percentage distribution, young adult and elderly population by area of residence, Mozambique, 2013.

Source: INE, Population projections 2007-2040.

Population data presented here suggest that in the Mozambican context, the problem of the environmental impact associated with population growth is directly connected to the difficult management of the urban and rural environment. This aspect may be attributed to the existence of two socio-economic systems in permanent antagonism and conflicting interests. In particular, the traditional informal sector/rural said, and the modern sector formal/Urban said, whose human occupation is distributed remarkably unevenly.

Indeed, environmental institutionalization in Mozambique at various times be shown as a double-breasted process discursively by political and financial aspects, as already pointed out in other contexts by Best (1989), Ibara and Kitsuse (1993), Hannigan (1995). It's understood that the difficulties of environmental management (urban and rural) in Mozambique become even more serious because they are conjugate to a weak human capacity, material and financial in environmental management agencies (Amaral, 2014a).

Whereas the survival of a community and its reproduction depend on the diversity of the ecosystem and the various forms of use and adaptation to the environment (Meneses, 2001, p. 4). It's easily understood that this rapid population growth affecting the environment in different ways in Mozambique. As micro level significant impacts, for example, the increasing opening of small family plantations in inappropriate places, grazing, burning, and woodcut for marketing and construction, open bites, traffic of people and vehicles in coastal regions. As the macro level: industrialization, pollution of water, air and soil, stealthy exploration of flora and fauna (leading to extinction of endemic species), that has been affecting all facets of human use of the environment producing

\footnotetext{
${ }^{2}$ Retrieved March 15, 2013, from http://www.Ine.gov
} 
specific results in each place, conditioned by historical and local circumstances.

It is the combination of the operation of these facts we can consider that population growth is a major cause of social and environmental problems in Mozambique. Although our research is to establish the first government action on environmental issues in the 1980s do not want to indicate that from 1975 to 1980, has been no action for the environment, such as the regulations for forest protection and promotion agriculture. These actions were environmentally friendly, but not taken and held with environmental vision its global imperatives and local. However, the degree of environmental institutionalization in Mozambique is still incipient and marked by great need of improvement of human resources and self-support capacity in terms of financial resources.

\section{Economy and Environment in Mozambique}

After independence in 1975, there was a downturn in the economy, mainly due to the abandonment of the main centers of production and the fact that it was introduced in the country a socialist one-party regime. Whose, economic support base would deteriorate gradually due the existence of protectionist policies and monopolization by the state of important production centers, not to mention the severe drought, 26 years of war, the exclusion of Mozambique in the formation of COMECON, and the establishment of new relations with Western countries.

The crisis established would only meet changes in the political and economic opening that took place in the 1980s, by the signing of the political and economic agreements with the World Bank and the International Monetary Fund in 1983. These agreements introduced in Mozambique the economic Recovery Program (ERP) and later the Economic and Social Rehabilitation Program (ESRP), historically understood as the beginning of economic neoliberalism in Mozambique (PNGA, 1995). The ERP/ESRP was a political-economic strategy, which eventually led the emergence of economic elite, a true national bourgeoisie, consisting mainly of senior government officials. However, as the environmental sphere defined as priorities for the country's restoration of agriculture, water supply and the restoration of basic health services and environment sanitation.

This program also had the role of positioning Mozambique in the ideological struggle between the two blocs, the East and the West. Where the country had to adopt the recommendations of the Bretton Woods Institutions (BWIs) and the government would no longer be provider goods and services, rising only to have the role of supervising the market, which obviously created many problems in the life of the Mozambican population used to a paternalistic and provident state. What is clear is that the opening of the regime, among other factors, was dictated by the economic crisis and the consequences of wars. The merit was to bring a package of reforms, together with the novelty of the environment issues as a crosscutting theme (PNGA, 1995; Amaral, 2014a).

However the extent that $53 \%$ of the population were live in absolute poverty in the period 1980-2000, on less than a dollar a day, and facing a lack of access to education as well as basic access to living conditions, such as, water supply and sanitation. This meant that most of the population lived directly dependent on natural ecosystems. Therefore, this framework appeared very interesting to Mozambique. Thus, the central idea of environmental economics in Mozambique went through the union of the fight against poverty and the struggle for environmental conservation. As is enshrined in the ideas that emerged in Stockholm (1972) and reflected in the 7th goal of the Millennium, which addresses the integration of issues of sustainable development principles into 
policies and programs of countries globally, with a view to reversing the degradation and loss of natural resources (Amaral, 2014a).

In this context, the funding channeled through the CDM and under the $\mathrm{UNFCCC}^{3}$, were welcome to reach some of the goals in the development, namely: poverty alleviation, from the generation of employment and income, Impulsion rural development; and Rationalization in energy use by increasing efficiency and energy conservation. Promoting the use of renewable energy, reducing dependence on imports of fossil fuels, waste utilization for energy generation, transfer of modern technologies and financial resources for the country, improving land use, promotion of afforestation and reforestation projects and improvement of the environment, with greater emphasis on risk management and natural disasters. The government programs and environmental strategies for fire and sanitation and that led to deep reforms in environmental public policy in Mozambique (PNGA, 1995).

According to the Environmental Status Report in Mozambique (2011) that it considers that the Mozambican economy in this period was largely based on agriculture, which reduced the possibility of reducing pressure on natural resources. This sector employed $80 \%$ of the economically active Mozambican population (9,600,000 inhabitants, in 2007). Most notably for women, and the country has 30 million hectares of arable land, of which only four million and are to be used as areas of accelerated agricultural development, with the usually inconvenient these same areas coincide with areas with fragile ecosystems, which contribute to environmental degradation, specifically for soil erosion, deforestation, degradation of wetlands, pollution and loss biodiversity. The central idea is that environmental problems (erosion, drought, floods, etc.) have a direct relationship with poverty.

The Mozambican GDP only began to experience a considerable growth from 1995 to mid-2000, from USD 144 to USD 400. The agriculture has always remained as the first sector with a $24 \%$ stake, the manufacturing industry with $13 \%$, trade and transport with $11.4 \%$ and $10.6 \%$ respectively, being last the various services with $7 \%$ and other sectors together with 34\%. Which demonstrates that the Mozambican economy is directly associated with exploration, pressure and unsustainable use of natural resources (REAM ${ }^{4}, 2011$; Amaral, 2014a).

Since the 1980s, the State of Mozambique recognizes that there is a direct economic relationship between the environment and development. The lower environmental quality would decrease the levels of sustainable economic development. For example, natural disasters (floods) suffered in five southern provinces of Mozambique in 2000, reduced the GDP of $7.5 \%$ in 1999 to $1.6 \%$ and inflation rose from $2.9 \%$ in 1999 to $12.7 \%$ in 2000; environmental issues are seen as essential for economic planning in Mozambique, aimed at poverty reduction and accelerated development (PARPA II, 2006). Most of the population depends on environmental goods; just consider for example, that rising fossil fuel prices and electricity in the period from 1980 to 2015, resulted in a high demand for wood fuel, are exerting so great pressure on forest resources (REAM, 2011).

Another aspect to consider in this relationship between economy and environment in Mozambique is that this country, since independence, depended on foreign aid to implement most of its development initiatives, including the environmental area, currently the country's economy tends to become stronger, whereas $55 \%$ of the state budget comes from domestic sources and the remaining $45 \%$ comes from external sources. For example,

\footnotetext{
${ }^{3}$ United Nation Framework Convention on Climate Change (UNFCCC). Retrieved from http://unfccc.int/2860.php

${ }^{4}$ MICOA. (2011). Report on the State of the Environment in Mozambique. "REAM" (Acronym in Portuguese)
} 
that in 1998 the external debt of Mozambique reached about six billion dollars. The Mozambican government invests $60 \%$ of the budget destined for the environment in sanitation activities, 30\% in environmental activities related to tourism, four percent for agriculture and six percent intended to MICOA (Economic and Social Plan, 2010).

Despite the economic decentralization policy adopted since the 1980s, the Ministry for Coordination of Environmental Action since its inception in 1994 remained dependent on the state budget funds, mainly to cover administrative costs and to implement its activities.

However, most of the resources to protect the environment and combat the negative environmental impacts comes from foreign cooperation partners, because the Mozambican state institutions still lack capacity to collect sufficient revenue. This is economic dependence, i.e. Mozambique has its environmental decisions conditioned to developed economies.

According the report on the state of the environment in Mozambique (MICOA, 2011), the environment sector and environmental issues continue to be transversal and non-priority subjects at all. Only USD10 million correspond to direct funding to MICOA and their subjects and subordinate bodies, which does not exceed 1.2\% (USD 71 million) of overall expenditure State, a figure that is lower than recommended by the world bank for environmental expenditure (1.4\% and $2.5 \%$ of GDP).

However, the government recognizes that this situation of dependence of most of the population to natural resources, impose the need to recognize that any program to combat poverty, goes through a deepening increasing how the quantity and quality of natural resources are maintained and operated so that contribute to income generation. The big Achilles heel is the disorderly occupation of physical space, which, according to the government contributes to greater environmental degradation, to exacerbate health problems, intensifying the existence of endemic diseases such as cholera, malaria etc. Thus, the central problem is the rural exodus and the increase of urban population and the increase of environmental problems, the direct dependence on the ecosystem for survival (Ream, 2011).

Since the beginning of the environmental process, the Mozambican government institutions had the support of various international organizations. This funding for the environment went through a dualistic logic, where the criteria to finance environmental activities necessarily have to mirror the government's interests, that is, they had to be a priority for the government, and had to be defined in agreement with the policies of the funding organizations. This was undoubtedly a breeding ground for the proliferation of a marketing practice in the implementation of the environmental issue, since, by the absence of decentralization, Mozambican environmental institutions can't collect revenue and the few collected by municipal and district court are channeled to the bottom national environment (FUNUAB) for further distribution.

This puts environmental institutions, dependent on the state budget, short of fulfilling its responsibilities. In this sense, a certain number of specific duties, commitments and incentives for environmental restructuring in Mozambique, moving the state sphere, financially dependent to the scope of the market, that is, the environmental public policy necessarily would be influenced, although in part, by the logic of the market, functioning as docile instruments of the will of the financial capital.

This logic focuses discomfort on the part of state bodies, against the direct funding managed by non-governmental organizations linked to environmental issues, after all the work of these organizations has been 
more incisive. In fact, with the emergence of environmental NGOs, the role of the state and environmental public policy moves from proactive environmental action for preventive; centralized and bureaucratic political action for more participatory, and national government direction to a more contextual. In this context, the role of the Mozambican government turned slowly into a functional need strengthened and reinvented whenever environmental protection and commercial competition, are at stake. Several factors still hinder the autonomy of Mozambican environmental institutions, and range from the nebulous political and economic decentralization, to the scarce human resources to work in the environmental area (Amaral, 2014a).

\section{Environmentalists Parties in Mozambique}

In Mozambique, parties or ecological movements emerge in the second half of the 1990s, in order to instill the notion and the urgency of environmental protection and the need for sustainable development in all spheres of Mozambican society, rights to a due claim the same from government authorities. In Mozambique, parties or ecological movements, didn't arise because of pre-existing social movements. Since the level of government, the notion of environmental protection requirements had been politically settled, eliminating therefore the existence of parties or movements for this purpose. Whereas political parties are a form of distribution of power in society and their appearance, in addition to being determined by related specific factors, the peculiar historical circumstances, also is associated with a change in society's conception and the common good (Fernandes, 1995).

Since its origin, the ecologist parties in Mozambique never intended in any way to achieve total political power, to form a government as expected of a political party in the traditional mold. Its purpose was to achieve the ideological power, seeking to influence the party that is in power, so that this government the best environmental conditions Mozambican society are guaranteed. The legal criteria for the definition of what is a political party in Mozambique is enshrined in the constitution of the republic. It argues that a political party should express political pluralism, contributing to the formation and manifestation of the popular will and being a fundamental instrument for the democratic participation of citizens in the country's governance, with its internal structure and functioning of political parties, be democratic (CRM, item 74, 2004).

Under these assumptions presented by the constitution, we consider that the functions of a political party consist of political socialization of its members and the creation of public opinion, as well as the harmonization of interests of citizens. It is also responsible for forming the political elite and channel popular concerns the party that is in power. So political parties reinforce and stabilize the political system of a country. As their training and the achievement of its objectives, the Constitution of the Republic of Mozambique, argues that political parties must be national movement to defend the national interests, strengthening the patriotic spirit of citizens and the consolidation of the Mozambican nation through education political and civic citizens, for peace and stability in the country (CRM, Artigo75, 2004).

Looking at the context of ecological political movements in Mozambique, we noted that its appearance was marked by conflicts based on power struggle and held by the environmental policy demand. Originality in the national policy framework where three ecological parties, it is actually the result of internal dissections of a single green movement emerged in the late 1990s and that gave rise to the green Party of Mozambique (PVM), the Party of Mozambique green (PEM), the Ecologist Party movement earth (PE-MT).

Although, according to the report of AfriMAP (2009), the extra-parliamentary parties in Mozambique are 
considered very unstable in their organization and mobilization, having very little social penetration and mobilization capacity, and giving them almost total discredit. Overall, it can be said that these environmental groups are creasing in the Mozambican political landscape, and was officially maintained as extra-parliamentary political parties, which in the first phase (1997-2004) were "beneficiaries" with the help of the Mozambican state, through monetary donations from international partners in the implementation of the multi-party system.

This discredit is deep with the externalization of the already traditional characteristics in such parties, which is that to remain silent throughout not election time, reappearing on the eve of elections, driven, among several reasons, the resources that have them it has been provided by the international community through the National Elections Commission (CNE). This is of such importance that in the 2004 elections, this amount of "help" has amounted to approximately two million dollar (AfriMAP, 2009).

Despite he seemed an irregularity in other media, the political context the financing of political parties is governed by the provisions of the Comprehensive Peace Agreement and the Law on Political Parties (Law no. 7/91), as well as the electoral law, which also includes provisions on political financing directed especially to the exercise of the election campaign. Ironically, these ecological movements can also raise money from the support that they given to other political parties by providing their electorate.

However, the performance of the Mozambican state "help" these organizations exposes the interest for the government that these environmental issues are on the agenda of the political agenda of the country. However, the manifesto of green represented by PVM reached only 0:40\% of the total votes in the 2004 elections, i.e. never reached the seats in parliament, which would not give them the right for electoral law to any funding. However, pluralism is a very recent phenomenon in Mozambique's political scene, and the emergence of new relevant political forces was hampered by the existence of a limit to input parties in parliament, the parties managed to five percent of the total being only represented valid national votes (The Europa World Year, 2004).

It is observed that this aspect is not respected by ecological parties and not for any other, except in relation to the first trans, awarded by the National Elections Commission, because this is the condition to have access to subsequent trans, not to mention that none of these parties respect the obligation to publish their annual accounts. The ecological parties in Mozambique take good relations with the Mozambican government formed by the Frelimo party since 1994. Indicating how the only problem that the government has not yet assigned a seat to the party, as required by regulation of the formation of political parties, evidencing in this respect an overall "selflessness" in to win some political power by environmental groups, although only ideological (Amaral, 2014a).

These movements doesn't have the ability to influence the government in its decisions. Becoming non-existent parties in the national political scene. Except in elections, they do nothing in order to appear in arena of country debate, leaving that criterion on the goodwill of the media or when invited by the ruling party (FRELIMO), avoiding as much as possible all dissonance with other parties by putting up as much as possible in neutral position. In a way that demonstrates a dose of submission to the ruling party and these are aspects that weaken the network of social relations of ecologist parties and does not clarify the Mozambican society which the foundations of the existence of ecologist parties in Mozambique.

In view of these political movements, their absence and inefficiency in the Mozambican environmental policy framework needs to inoperability of environmental laws and regulations, the lack of environmental 
monitoring to ensure their full operation. That is, they stated that there is no multi-party system in Mozambique, there is still repression against freedom of expression and partisan action. These ecological movements have the legal characteristics for consideration of what would be a political party in the Mozambican legal context. They are permanent, participate in the functioning of the constitutionally established government system, and have political representation, although extra-parliamentary and weak. However, we consider that would still be faced with pressure groups, as these are marked by deficiencies in the execution of their political ideology.

Can thus surmise that in Mozambique, one of the major obstacles in the institutionalizing environmental process at political level is on the promiscuity between ecological political movements and the government excessive politicization actions. The environmental groups that initially appeared to channeling the specific demands of the greening of the supporters of economic and social development process, quickly turned into electoral political parties officially registered with the function of channeling the concerns of a broader and more diverse electorate. However, unprepared and disabled, can't find space for the efficient performance of his new role, for lack of human resources. For they left only the function to participate, albeit fictitiously of elections, with veiled aim to be one of several other parties and thus perpetuate the politically correct cover of multiparty democracy in Mozambique (Amaral, 2014a).

These transformations undergone by Mozambican ecological parties in its historical path crystallize a clear separation between the citizens and party representatives that becomes visible in declining voter turnout. Mozambicans ecological political parties are now more distant from their electorate; having less power and legitimacy, but enjoying greater social privileges because emerge as society representatives from the State, but exert opposite role, are not intermediaries between the government and the Mozambican society, but the government has become the connection between Mozambican society and ecological political parties.

\section{Changes in Mozambican Environmental Policy}

Analytically, this article divided the environmental institutionalization process in Mozambique in two great periods to consider, 1980-1992, and 1992-2015.

The political action on the environment began after independence in 1975, with the approval of the firefighting policy and sanitation campaigns of the environment in different sectors. However, it was from the 1980s that environmental notion began to be systematized and deserve special attention, culminating in the establishment in 1982 of the Environmental Management Unit, based at the National Institute of Physical Planning (INPF).

The fundamental goal was to devise an institutional device able to integrate environmental principles in the country's development process. The National Council for Sustainable Development (CONDES) under the six Article of the Environment Act. It was created as an Advisory Board of the Ministers Council and consultation forum of public opinion on environmental issues and legislation on protection measures environment, the prevention of environmental damage, the rights and duties of citizens, responsibilities, offenses and penalties in environmental enforcement, with the participation of communities (National Report of Mozambique Consulting, 2009).

From 1985, it was proposed to the Mozambican government the creation of ministerial Environment Council, assisted by a secretariat, with the assistance of the United Nations Environment Program and the 
International Union for Conservation of Nature (IUCN). Thus, in 1987 the Minister of Mineral Resources was appointed to head the environmental management process in Mozambique, assisted by the Minister of Construction and Water. Since 1980, Mozambique has effected various activities at different levels. Focusing on the establishment of the National Training Plan on the implementation of the Clean Development Mechanism, financed by the Governments of Denmark and Netherlands, implemented by UNEP Collaborating Centre, executed by the Engineering Research Centre production unit from Eduardo Mondlane University in collaboration with the National Directorate of Environmental Management (REAM, 2011).

The creation of the interagency group on Climate Change in the country, to develop the first national inventory of greenhouse gases with data from 1990 to 1998; Preparing the report "Summary of Available Information on Adverse Effects of Climate Change"; Preparation and project proposal submission Netherlands Climate Change Studies Assistance Program (NCCSAP). Vulnerability study of the Mozambican economy to climate change under the US Country Study Program project; Conducting outreach activities and public awareness on issues related to some environmental conventions. Establishment and training of national technical group for the implementation of the clean development mechanism, consisting of the following ministries: MICOA, MINAG, ME, MIC and UTIP. Thus, the environmental sphere in Mozambique in its early days (1980-1992) presented levels of problems that were taking gigantic proportions for lack of compliance with environmental protection policies, according to the official documents of MICOA (PNGA, 1995; REAM, 2011).

This period was marked by strong pressure on natural resources. Simply consider the incentives for strong exploitation of natural resources in the official Government documents related to mining exploration, although it's considered that all facets of human use of the environment produce results specific in each place, conditioned by historical circumstances and places, such as those experienced in the Mozambican context that period. In the period of 1980-1992, the Mozambican political discourse was based on rhetorical statements of management theory for decentralization of power, defending the community involvement in the management of local problems, and necessarily requires the state to decentralize some functions, powers and resources, although it is still under its control (MICOA, 2002; Amaral, 2014a).

In this light, the government considered that one of the advantages of decentralization would be to allow decisions to be taken by the units located in the lower levels of the Mozambican social organization, adding that people who experienced the problems were the most appropriate to address them in site, thus saving time and money. The importance of this decentralization is the defense of local solutions of the problems experienced by local communities. In this case, including users and business class that explores economic units at its periphery (Moreira, 1984).

This theory used by the Government was demonstrating its belief that the environmental problems of human origin could be solved through civic education and public participation in the environmental management process. In this period, the environmental issue in Mozambique was built at the government level. Having as context a financial dependence scene, lawlessness and the need to increase human capacity, so for example, the Mozambican government networking different International institutions that can finance training, institutional capacity building and finance the construction and resolution of environmental or risk object problems, according illation thought of Becker (1992).

The second period, from 1992 to 2015, just after the Rio-92 Conference, in which the environmental sphere 
experienced significant changes in the institutional landscape on the environmental issue in Mozambique. The RIO-92 was the first global environmental event in which Mozambican government participated. Which makes it understandable that this has aroused much interest to the government and the various institutions of the Mozambican public and private sector, that directly or were indirectly involved in this problem, especially with regard to aspects concerning the conservation and preservation of the environment and sustainable use of natural resources (Amaral, 2014a).

In this second period, the Mozambican environmental scenario now has a new actor, the civil society, made up of International and National NGOs, associations and academics, i.e., administrative and research staff, paid with fund-strong fund programs and sophisticated, institutionalized links in relation to media and legislators (Hannigan, 1995, p. 61).

The nature of the demands and rhetorical claims of civil society regarding the environmental issue in Mozambique passed hence the need for protection of the environment. Thus, the Mozambican civil society has to defend that environmental education is one of the urgent measures, as this would allow for interaction between the various partners in solving problems, making them more aware and concerned to react to reduce the impact on the environment. Providing a precise and well-defined plan to consolidate each of the existing population centers, thus requiring the realistic government policies whose implementation is remarkable. Civil society based his rhetorical statements in consideration of citizens as victims of government indolence in offering a quality environmental education population. Thus, their findings will focus on the shortage of financial and human resources to care for the environment, basing their actions on the suggestion of a set of necessary actions and properly implemented would prevent economic spending (Amaral, 2014b).

However, it was in this second period that the overall responsibility for environmental management in the political, economic and social context had become the Ministry for Coordination of Environmental Action (MICOA). Which is the central body of the state apparatus that directs the implementation of the policy environment, coordinates, advises, monitors and encourages proper planning and use of natural resources of the country, according to the principles, objectives and tasks set by the Council of Ministers.

It is important to understand here that in adopting the ideas and demands on the environment, Mozambique entered the great dilemma of neoclassical economic approach that can be summarized in the fact that if you want economic growth to eliminate poverty, and the mold economic growth previously established, burdened the environment (Romeiro No. 102, Sept. 2001; Cavalcanti, 1996, pp. 322-323), born of this that government need for legal regulation and a constant search for effective environmental justice, blunting hence the need for reform in the Mozambican legal framework.

That's, on 3 June, 1992 was also created the National Commission of the Environment (CNA), by decree of President Joaquim Alberto Chissano. Its mission is coordinating the national level the environmental activities, promoting the management, conservation and rational use of the natural resource base of the country, promote and support the education of Mozambicans in the field of environment and foster interdisciplinary in executing and enforcement of the recovery actions of natural structures. In the same decree was named John William Kachamila, then minister of mineral resources as chairman and João Mário Salomão then Minister of construction and water, as vice-chairman of the committee (Presidential Decree 3/92 and 6/92 of 3 June).

This committee comes as the need to establish a body to coordinate and handle the business for the 
environment, given the fact that the Mozambican government has ratified the African Convention on the conservation of nature and natural resources, the Convention on International Trade in wild fauna and flora declared as endangered. Also by the fact that Mozambique has been registered in the International Union for Conservation of Nature and natural resources (IUCN), the institution that financed activities to the institutionalization of environmental issues in Mozambique.

Literally, environmental history of Mozambique was marked by redefinitions at various levels of social spheres. As evidenced by a series of movements (economic, political), in order to change public policies, production processes and the company's lifestyle in favor of a development model that should be sustainable at all levels of social spheres, to incorporate environmentally sustainable practices in all parts of the Mozambican human life. These transformations undergone in the Mozambican political and economic framework to fall globally in a historical context marked by environmental controversies at political and economic level.

Thus, considering the historical moments of the environmental debate, we can say that in Mozambique the environmental issue in its genesis has strong links with the economic aspect, which intensified at the same time for the environment and pari passu effectively transformed the concern for the environment in economic cause. From the 1980s Mozambique lived the consequences of these changes in the global development paradigms. Where he is an old view of the world that preached the idea of a development based on continued economic growth, in the conquest and transformation of nature, the excessive use of natural resources and industrial mass production, to a new total view of the world marked by the need for sustainability.

In fact, the environmental public policy in Mozambique has direct influence of the global consequences of the Stockholm Conference (1972), which had as its main result the creation of UNEP (the United Nations Program for the Environment), the first global environmental agency, supports financially and institutionally the environmental institutionalization process in Mozambique. Through eco-development approach (Sachs, 1976), the environmental issue has to be understood as a crosscutting aspect of a national development model, where the development process only became possible by equating the trinomial: ecological balance, economic efficiency and equity social (Carvalho, 1987).

This proposal reshaped the global socio-economic trajectory, making action at all levels were driven to replace the growing production model by the overall balance, making use of this middle way which appeared in June 1973, adding in addition to environmental issues, social, the participative management, ethics and cultural (Gonçalves, 2005; IUCN, WWF, Brundtl and Report).

It is noteworthy that the conventions once ratified opened doors to the achievement of several mainly economic and political benefits, that due to the context in which Mozambique was in, particularly the political and economic crisis of the 1980s and 1990s was just what more help in the reconstruction of Mozambique's social fabric. No doubt that these conventions came true as buoys salvation, to the extent that presented themselves as complete packages not only instructing on how to implement the conventions. But also accompanied by funding programs, education, training, information and public education, public participation, public access to information and international cooperation, just to encourage actions that facilitate the implementation of environmental conventions, and favor the development and transfer technologies to less developed countries through conventions funds, protocols funds, among others (UNFCCC, article 4 and 6, COP 7, $8)$. 
Indeed, in Mozambique, under the auspices of the new development collaborates (IMF, World Bank), remarkable environment pro soul movements are beginning to speak in support of environmental sustainability, although only at government level. Going to demand a greater concern and participation in the points of the global environmental agenda, which is verifiable throwing a quick glance at the place the subject environment, has come to occupy in the political, economic, and social life of the country, although as a crosscutting theme for 35 years (1980-2015). Undoubtedly, in a prominent place in the Mozambican governance agenda, considering that with only 41 years as an independent country Mozambique is already a signatory to several treaties, agreements and international conventions relating to the environment (Amaral, 2014a).

Clearly, the environmental problem itself wasn't and not follows being Mozambican national priority. Because since priorities are combating poverty and the urgent search solution to the political, social and economic crisis brought on its territory. However, it is clear that the environmental phenomenon in Mozambique is undoubtedly a result of the interaction between two great actors. On the one hand, the Government of Mozambique (1975) and on the other transnational institutions such as the UN, the World Bank, the IMF and its lending policies. In a first period getting out the population and civil society, notorious in the second period and which is gaining strength and voice in current days.

\section{Final Considerations}

The Mozambican environmental institutional framework crystallized considerably in the decade 1990, extending to almost all sectors and subsectors of the Mozambican state and incorporating issues related to sustainability. On the one hand, as a way to perform many of the arising recommendations on the Stockholm Conference (1972) and the other as a way to equip and modernize the national environmental policy framework (Rio 1992), so that its then state its infancy, did not constitute an impediment of foreign funding to the state budget.

In general, Mozambican environmental institutions have a structure regulated by norms and rules, organized in mixed form for human and technological equipment elements. These institutions have values or codes of conduct, which in itself requires a hierarchical organization (authority and subordination), thereby demonstrating cohesion between the components, a unified structure. With this study we observed indicators of a growing environmental institutionalization in Mozambique although as an unfinished process, because despite being established an efficient bureaucratic framework in terms of the possibility of association for the environment, there is a strong need for articulation means at all levels, from the government, social movements, national and international partners, and other stakeholders.

So that the environmental demands become institutionalized to the individual consciousness level of the Mozambican citizen. Guaranteed greater success in the implementation of environmental policies, working as true means by which the Mozambican citizen can adjust to the environment, be it natural, social and / or supernatural, in that many of the conservation areas or conservation in Mozambique, they are also determined based on the magical-religious practices linked to the territory.

Mozambican environmental institutions, as cultural, play a key role in the socialization process, to the extent that define the positions, status and roles of the parties involved in the environmental institutionalization process. That is, they also aim to make an individual becomes a member of society in its entirety, covering also the 
environmental aspect. We also consider that the Mozambican environmental institutions propose to ensure that individual, private and collective actors in the Mozambican context act based on interest. Nevertheless, always protecting the interest in the environment, hence the importance of the role of the state and public policies that focus on the supervision and regulation of pursuing these interests.

In Mozambique, initiatives or deindustrialization alternatives to limit environmental degradation are applied only to a marginal extent. This is due to several factors related to limited economic viability and scarce ideological and political support, because although veiled at the level of political discourse of sustainability, co-exist with remnants of the previous paradigm of development, basically the idea of exploitation and perpetuation of domination of nature and scope of economic growth at any cost.

The environmental restructuring processes in Mozambique are developing in a context of greater interdependence between institutions. Private economic actors, the economic mechanisms and market the exercise increasingly important role in this (re)structuring environmental process. Seeking the replacement of the environmental model top-down, as originally adopted, for a model of participatory environmental regulation, through which the performance and evaluation of environmental processes will be based on ecologically desirable criteria.

There is a dependency on environmental institutions, especially regarding the economy, but the existence of the environment on the sector in all organs of the Mozambican state, already reveals the consideration of the environment as a social sphere that is to be autonomous, able to influence the performance of all other social spheres. The environmental issue in Mozambique did not arise from the perception and popular Claim or lay of the environmental problems the way of the pioneering countries in this issue, but as consequence of the environmental issue universal process.

Indeed this "environmental fad" reflected in "disbelief" in the political and economic subordination of environmental institutions, especially in the weakness of the Mozambican environmental institutional framework. That despite having rooted structural properties does not allow reproduction of the desired environmental behavior at the level of the Mozambican popular consciousness. Despite all external influence that might have existed in this environmental institutionalization process, it is important not to put into question the sovereignty of the Mozambican state in these negotiations with multinational institutions. The membership of the Mozambican government will global environmental agenda was a rational and hegemonic action, seeking the incorporation of global environmental component, for analysis and problem solving at the local level.

In addition, regardless of how the environmental issue arose in Mozambique, the institutional level, this represented a gain and a breakthrough in that it allowed greater awareness, regarding the need for sustainable use of the environment. While the fact that exogenous factors have influenced the process of environmental issues arising in Mozambique does not mean it has been by imposition, but through a negotiation process. In general, the configuration of the contextual backdrop to the emergence of environmental problems in Mozambique was markedly institutional. Making the citizen a passive receiver of the decisions taken at government level, with no vectors involving Mozambican citizens in a profound way in environmental discussions and its importance.

The environmental situation in Mozambique has evolved considerably with the promulgation and dissemination of various national policies related to the environmental area. Reflected in the internalization of responsibility by the government on the management and conservation of the environment in all its strategies, 
policies and institutional sectors. Thus, in the Mozambican institutional framework on the environment, we note that there is a profound question that focuses on environmental management, and which can be summarized as the existence of economic environmental institutions and politically dependent on external funding and the absence of an economically sustainable solution national scale.

In this analysis on the environmental institutionalization process in Mozambique, we could clearly see that the emancipation from the international external funding, for making decisions that result in the durability of environmental actions, is one of the conditions for sustainable management of environmental resources to scale site. Which demands independence, not only political but also economic and implies a participatory and democratic process, allowing the exercise of an active environmental citizenship (UN-Habitat, 2007). Thus, the environmental sphere, or rather the environmental rationality would be present in all institutional sectors of Mozambican society.

The legal instruments for the borderless environment of doubt represent a colossal gain for the process of institutionalization. Nevertheless, it would be of major importance, the adequacy of these new realities and challenges experienced by Mozambique nowadays. Given that the current context is shown distinct from living in the 1980s, particularly refer to the adequacy of fees, fines, and penalties provided by law for those who break the law and if this adjustment is not carried out promptly, Mozambique incurs the possibility of having obsolete institutions for environmental management for long.

The support received by Mozambique to boost the environmental issues process, shouldn't be seen as something negative in itself, on the contrary. Despite concerns and conflicts that were involved in this "help", excellent gains are likely to be identified such as: the organization in terms of environmental knowledge, environmental legislation, technical personnel, exchange of experiences etc., were provided by this foreign support. In the Mozambican party political context, we believe it would be of paramount importance to supervision of extra electoral activities of ecological political parties. As well as supervision of the finances of political parties in general, so that to avoid considerable public spending on party organizations politically non-existent in the life of the country.

Thus, for example, the National Elections Commission (CNE) would ensure that all political parties to inform and justify the use of public funds allocated to them during the election campaign. The political and economic dependence scenario that occurs emerged as consequence of exogeneity of environmental issues in Mozambique. Which also led to the existence of a marketing practice of environmental issues, to the extent that the actors involved with environmental issues have more chance to take particular economic and political gains as result of this "dedication" to the preservation and conservation of the environment, both the State and private levels. Just as indicators to analyze, the times for approval of certain environmentally unsustainable projects shall be above the law and environmental regulations. Subject to deal in another article.

\section{References}

Afrimap. (2009). Relatório sobre a Democracia e a participação política em Moçambique. Retrieved from http://docplayer.com.br/6271411-Mocambique-democracia-e-participacao-politica-um-relatorio-publicado-pelo-afrimap-e-pe la-open-society-initiative-for-southern-africa.html

Amaral, G. A. do. (2014a). O processo de institucionalização da questão ambiental em Moçambique-1980-2000. Dissertação de Mestrado em Sociologia. 145 folhas. 
Amaral, G. A. do. (2014b). Reflexo de conflitos sócio-ambientais na era da sustentabilidade em Moçambique: O caso da Costa do sol. In Seminário fluminense de Sociologia, GT Sociedade e meio ambiente, PPGS-UFF.

Becker, F. (1992). O que é construtivismo? Revista de Educação AEC, Brasília, 21(83), 7-15.

Best, J. (1989). Rhetoric in claim-making. Social problem, 34(2), 101-121.

Buttel, F. H. (1996). Environmental and resource sociology theoretical issues and opportunities for synthesis. Rural Sociology, 61, 56-76.

Calvacanti, C. (Ed.). (1996) Desenvolvimento e Natureza: Estudos para uma Sociedade Sustentável. Cortez, São Paulo.

Carvalho, P. G. M. (1987). Meio ambiente e políticas públicas- a atuação da FEEMA no controle da poluição industrial. Campinas, UNICAMP.

Catton, W. R., R. E., \& Catton, W. R. (1978.) Environmental sociology: A new paradigm. The American Sociologist, 13(4), 41-49.

Catton, W. R., \& Dunlap, R. E. (1994). Struggling with human exceptionalism: The rise, decline and revitalization of environmental Sociology. The American Sociology, 25(1), 5-30.

Dunlap, R. E. \& Catton, W. R. (1980). A new ecological paradigm for post-exuberant sociology. American behavioral scientist, 24(1), 15-47.

Fernandes, A. J. (Ed.). (1995). Introdução à Ciência Política: Teorias, Métodos e Temáticas. Porto: Porto Editora.

Ferreira, L. da C. (2004). Ideias para uma Sociologia da Questão Ambiental - teoria social. Sociologia ambiental e interculturalidade. Desenvolvimento e Meio ambiente, 10, 77-89.

Hannigan, J. A. (1995). Sociologia ambiental — a formação de uma perspetiva social. Lisboa, Instituto Piaget.

Ibara, P. R., \& Kitsuse, J. L. (1993). Vernacular constituents of moral discourse: na interactionist proposal for the study of social problems. In J. A. Holstein \& G. Miller (Eds.), Reconsidering social constructionism: Debates in social problems theory (pp. 25-58). Nova Iorque: Aldine de Gruyter.

McElroy, A., \& Townsend, P. K. (1996). The ecology of health and disease-A focus on adaptation. Medical anthropology in ecological perspective. Colorado: Westview Press, USA.

Meneses, M. P. G. (2001). A natureza, a biodiversidade e o conhecimento local: qual o papel dos cientistas sociais? UEM/FL/DAA, Maputo.

Moreira, M. E. (1984). Glossário de termos usados em Geomorfologia Litoral. Centro de Estudos Geográficos, Lisboa.

Sachs, I. (1976). Environment and styles of development. In W. H. Matthews (Ed.), Outer limits and human needs: Resources and environmental issues on development strategies (pp. 41-65). Uppsala, Dag Hammarskjöld Foundation.

The Europa World Year. (2004). Book II: Mozambique, political organization-International organizations countries. Europa Publication (45th ed.). Taylor \& Francis Group. Retrieved from http://www.europaworld.com

UN-HABITAT. (2007). Perfil do sector urbano em Moçambique. Retrieved from mirror.unhabitat.org/pmss/getElectronicVersion.aspx?nr=2748\&alt=1 


\section{Appendix}

\section{Government Official Documents}

Constituição da República de Moçambique, 2004.

Convenção Quadro das Nações Unidas sobre Mudanças Climáticas, aprovada pela Assembleia da República pela Resolução n. ${ }^{\circ}$ 01/94, de 24 de Agosto.

Decreto n. ${ }^{\circ} 1 / 2003$, Altera os artigos 20 e 39 do Regulamento da Lei de Terras.

Decreto presidencial 3/92 e 6/92 de 3 de Junho.

Lei de Florestas e Fauna Bravia, Lei n. ${ }^{\circ}$ 10/99, de 7 de Julho, BR n. ${ }^{\circ} 27,4 .^{\circ}$ Suplemento.

Lei de Minas, Lei n. ${ }^{\circ}$ 14/2002, de 26 de Junho, BR n. ${ }^{\circ} 26$, I. ${ }^{a}$ Série, Suplemento.

Lei de Terras, Lei n. ${ }^{\circ}$ 19/97 de 1 de Outubro.

Lei do Ambiente; Lei n. ${ }^{\circ}$ 20/97, de 01 de Outubro, BR n. ${ }^{\circ} 40$, I. ${ }^{a}$ Série.

Lei do Turismo, Lei n. ${ }^{\circ} 4 / 2004$, de 17 de Junho, BR n. ${ }^{\circ} 24$, I. ${ }^{a}$, Suplemento.

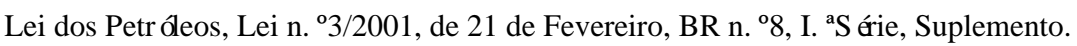

MICOA. (2001). Agenda 21 em Moçambique, Moçambique.

MICOA. (2002). Relatório Nacional de Moçambique, Cimeira Mundial Sobre Desenvolvimento Sustentável.

MICOA. (2003). Plano de capacitação Nacional Sobre a Implementação do Mecanismo de Desenvolvimento Limpo, Moçambique.

MICOA. (2004). Relatório da Avaliação Participativa da Vulnerabilidade do País às Mudanças Climáticas.

MICOA. (2004). Síntese informativa Disponível sobre Efeitos Adversos das Mudanças Climáticas em Moçambique.

MICOA. (2011). Relatório sobre o Estado do Ambiente em Moçambique.

PLANO DE ACÇÃO PARA A REDUÇÃO DA POBREZA ABSOLUTA 2006-2009 (PARPA II) (02 de Maio de 2006) Versão

Final Aprovada pelo Conselho de Ministros, Maputo.

Protocolo de Quioto, aprovado pela Assembleia da República, Resolução n. ${ }^{\circ}$ 10/2004, de 28 de Julho.

Regulamento Ambiental para o exercício da Actividade Mineira, Decreto no 26/2004, de 20 de Agosto, BR n. ${ }^{\circ} 33,1^{\text {a }}$ série, $2^{\circ}$ suplemento.

Regulamento da Lei de Florestas e Fauna Bravia. Decreto $n^{\circ}$ 12/2002, de 7 de Julho.

Regulamento da Lei de Minas, Decreto n ${ }^{\circ}$ 28/2003, de 17 de Junho, BR n. ${ }^{\circ} 28,1^{\text {a }}$ série.

Regulamento da Lei de Terras, Decreto n. ${ }^{\circ} 66 / 98$, de 8 de Dezembro.

Regulamento de Padrões de Qualidade Ambiental e de Emissão de Efluentes; Decreto n. ${ }^{\circ}$ 18/2004, de 2 de Junho, BR n. ${ }^{\circ} 22$, I. ${ }^{a}$ Série, Suplemento.

Regulamento de Pesticidas, Diploma Ministerial n. ${ }^{\circ}$ 153/2002, de 11 de Setembro, BR n. ${ }^{\circ} 37$, I. ${ }^{a}$ Série, Suplemento.

Regulamento do Licenciamento da Actividade Industrial, Decreto n. ${ }^{\circ}$ 39/2003, de 26 de Novembro, BR. n. ${ }^{\circ} 48$, I. ${ }^{a}$ Série, e Revoga o Decreto n. ${ }^{\circ} 44 / 98$, de 9 de Setembro.

Regulamento Relativo ao Processo de Auditoria Ambiental, Decreto n. ${ }^{\circ} 32 / 2003$, de 12 de Agosto, BR n. ${ }^{\circ}$ 34, I. ${ }^{a}$ Série.

Regulamento sobre gestão de Lixos Biomédicos, Decreto n. ${ }^{\circ}$ 8/2003, de 18 de Fevereiro, BR n. ${ }^{\circ} 7$ I. $^{a}$ Série, $2{ }^{\circ}$ Suplemento.

Regulamento sobre o processo de Avaliação do impacto Ambiental, Decreto n. ${ }^{\circ}$ 45/2004, de 29 de Setembro, BR n. ${ }^{\circ} 93$, I. ${ }^{a}$ Série, Suplemento e Revoga o Decreto n. ${ }^{\text {7 } 76 / 98, ~ d e ~} 29$ de Dezembro.

\section{Policy and Sectoral Strategies}

Estratégia Nacional para a Eliminação da Gasolina com Chumbo (em processo de aprovação pelo Conselho de Ministros);

Plano Distrital de Desenvolvimento, 1998.

Plano Económico e Social, 2010.

Política e Estratégia de Desenvolvimento de Florestas e Fauna Bravia, Resolução n. ${ }^{\circ}$ 8/97, de 1 de Abril, BR n. ${ }^{\circ}$ 14, I. ${ }^{a}$ Séri, Suplemento.

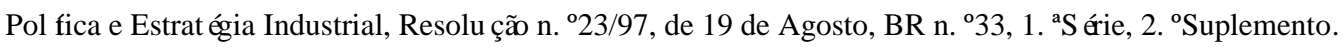

Política Nacional de Terras e Estratégia Nacional de implementação, Resolução n. ${ }^{\circ}$ 10/95, de 17 de Outubro, BR n. ${ }^{\circ}$, Suplemento.

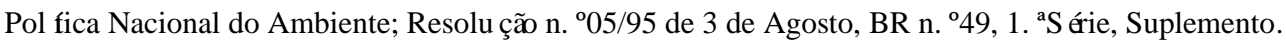

Politica Nacional do Turismo, Resolução n. ${ }^{\circ}$ 2/95, de 30 de Maio, BR n. ${ }^{\circ} 22$, I. ${ }^{a}$ Série, $3 .^{\circ}$ Suplemento. 
Programa Nacional de Gestão Ambiental, MICOA, Maio de 1996.

\section{International Documents}

United Nation Convention on Biological Diversity (UNCBB). (1992). Retrieved from https://www.cbd.int/doc/legal/cbd-en.pdf United Nation Convention to Combat Desertification (UNCCD). (1994). Retrieved from http://www.unccd.int/Lists/SiteDocumentLibrary/conventionText/conv-eng.pdf

Brundtland Report. ONU (1987). UNCED-92. Retrieved from http://www.un-documents.net/our-common-future.pdf 